\title{
Analysis of Income Distribution Among Goat Farmer Households in Banjarnegara District, Central Java Province Indonesia
}

\author{
Moch.Sugiarto ${ }^{1)}$ and Abdul Aziz Ahmad²) \\ 1) Faculty of Animal Science, University of Jenderal Soedirman, Jl.Dr. Soeparno Purwokerto 53123 Indonesia \\ 2) Faculty of Economic and Business, University of Jenderal Soedirman, J.HR Boenyamin Purwokerto 53122 Indonesia \\ Corresponding author email: zoegic@yahoo.com
}

\begin{abstract}
The objective of this study was to describe the structure of household's income of goat farmer and analyze the distribution of goat farmer household's income in Banjarnegara. For this analysis, Banjarnegara district was divided into three agro ecological zones on the basis of altitude, i.e. low, medium and high land. 180 goat farmers were selected using multistage sampling and data were measured using descriptive statistic and Gini Coefficient. The study concluded that goat farming as a side job contributed $29 \%$ of total household income. The income from non-goat farming remain dominating a structure of household income by $71 \%$. There was a high inequality household income among goat farmers with Gini Coefficient of 0.562 . The high level of total income inequality was due to a greater relative inequality in non-goat farming income. Since there was a relationship between farm size and income, increasing the number of goats must be actualized to the goat farmers with no other livelihood. This would be able to reduce inequality of total income of goat farmers.
\end{abstract}

Key words: income structure, inequality, gini coefficient

Abstrak. Penelitian ini bertujuan menggambarkan struktur pendapatan rumah tangga peternak kambing dan menganalisa distribusi pendapatan rumah tangga peternak kambing di Banjarnegara. Dari hasil analisa, kabupaten Banjarnegara terbagi menjadi tiga wilayah agro ekologi berdasarkan ketinggian yaitu dataran rendah, sedang dan tinggi. 180 peternak kambing dipilih secara multistage sampling dan data diukur dengan statistic deskriptif dan koefisien Gini. Disimpulkan bahwa peternak kambing sebagai pekerjaan sampingan menyumbang $29 \%$ dari total pendapatan rumah tangga. Pendapatan di luar beternak kambing tetap mendominasi struktur pendapatan rumah tangga sebesar 71\%. Ada ketidakrataan pendapatan yang tinggi karena besarnya ketidaksamaan relatif dalam pendapatan diantara peternak kambing dengan koefisien gini sebesar 0.562. Tingginya ketidaksamaan total pendapatan disebabkan karena ketidaksamaan pendapatan relatif pada pendapatan di luar beternak kambing. Karena adanya hubungan antara jumlah hewan ternak dan pendapatan, maka untuk jumlah kambing perlu ditingkatkan bagi peternak yang tidak mempunyai penghasilan lain. Hal ini akan dapat mengurangi ketidaksamaan total pendapatan peternak kambing.

Kata kunci: struktur pendapatan, ketidaksamaan, koefisien gini

\section{Introduction}

Characteristics of underdevelopment in rural areas of Banjarnegara District demand improvement. Livestock development was aimed at improving welfare and reducing poverty in rural areas. Todaro (2006) emphasized that development is a planned process that includes a variety of fundamental changes in social structure, attitudes of society, and institutions, income inequality and poverty.

Goat farm development in Banjarnegara District is intended to increase farmers' household income. In the context of community development, goat farming is expected to reduce poverty and create new productivity in rural areas. Ogunniyi et al. (2011) noted that poverty is the result of low income and a lack of assets ownership. Natural resources and farming culture of Banjarnegara society is expected to be an important asset in the alleviation of rural poverty.

Goat farm in Banjarnegara has evolved as a side business to support beef cattle farming. The development of goat population in 
Banjarnegara reached $185,998.00$ heads in 2013 and over the last 3 years (2012-2014) recorded a population growth of 2 percent per year (Banjarnegara Statistic Bureau, 2015). The growth of the goat population drives a business scale increase of rural farmers, which can further lead to increased revenue. Nevertheless, the scale of goat ownership was absolutely varied among farmers in the rural area. The different characteristics of goat farming can encourage productivity differences between farmers. This situation can ultimately lead to differences in household income of goat farmers in Banjarnegara.

Goat farm development in Banjarnegara has the purpose of increasing farmers' revenues which is one indicator of farmers' welfare. Agwu and Orji (2013) explained that the unequal income distribution, as an indicator of rural development and growth, is often associated with poverty. Study of farmers' income distribution is essential to understand the level of inequality between different groups of farmers' income. Related to this, the study was aimed to (1) describe the structure of household's income of goat farmer (2) analyze the income distribution of goat farmer household's in Banjarnegara.

\section{Materials and Method}

The study was conducted in Banjarnegara District, Central Java Province of Indonesia in November 2014. Survey method was used to obtain the facts of social, economic, or technical aspects of goat farming through interviews and observations to the goat farmers. A total of 180 goat farmers were selected as respondents by multistage sampling method. First, research sample areas were determined by stratified random sampling based on the altitude (high, medium and low). At each strata, sub districts were selected at least 20 percent as sample area. Second, 30 respondents (farmers) were chosen by a quota sampling method from each of the selected districts.

Primary source of the data was used for the study. This was actualized with the selected questionnaire administered to respondents. Previously trained enumerators assisted in data distribution and collection. Variable observed was the household income from goat farming and non-goat farming. Data were subject to descriptive statistic to depict the structure of household income of goat farmers. Gini coefficient was used to analyze the distribution of household income of goat farmers in Banjarnegara.

Income inequality was measured using Gini Coefficient. Gini Coefficient gives the same ranking in a concave social welfare function. It can be presented in the area between the Lorenz curve and the diagonal line which shows complete equality. The measurement had been used in many research fields, from the last periods, like Atkinson (1970), to recent years. The use of Gini Coefficients in the measurement of the level of disparity also has a lot to do in the field of agriculture and animal husbandry. Recent studies by Puskur (2006) utilized the tapped Gini Coefficient index to measure the disparity in the ownership of cattle in India, and from Fang, Zhu and Deng (2013) that proved the extent of distribution in China. Birthal et al. (2014) used Gini Coefficient to measure income disparities among farmer households in India.

In this study, household income of goat farmers was calculated by summing the income earned from goat farming and non- goats farming within a year.

$\mathrm{I}=\mathrm{Pk}+\mathrm{NPk}$, description :

$\mathrm{I}=$ Total income of farmer households (Rupiah/year)

$\mathrm{Pk}=$ Income of goat farming (Rupiah/year)

NPK = non- goat farming income (Rupiah / year)

The value of Gini Coefficient illustrates that number 0 corresponds to perfect income equality (everyone has the same income) and 1 
corresponds to perfect income inequality (one person has all the income, while everyone else has zero income). Gini Coefficientis was estimated according to Bellu and Liberati (2006) as follows:

$$
G=1-\sum_{1}^{n} \cdot f_{i}\left(Y_{i+1}+Y_{i}\right)
$$

$\mathrm{G}$ : Value of Gini Coefficient

$\mathrm{fi}$ : The proportion of total farming households in class $\mathrm{i}$

$\mathrm{Yi}$ : The proportion of total household income cumulatively in class $i$

Inequality criteria based on income was low with Gini Coefficient < 0:35, moderate was 0.35 to 0.5 , and high was $>0.5$. De maio (2007) stated that Gini Coefficient was used as a continuous variable ranging from 0 completely equal distribution of equivalent income, to 1 - completely unequal distribution of equivalent income.

\section{Results and Discussion}

\section{Income of Goat Farming}

Goat farmers in Banjarnegara were within the range of productive age averaged 47.7 years, Elementary School graduates, and family size was 1-10 people with average 4 persons. Goats were kept in small scale farm (1-18 heads) with an average 3 heads.

Net farm income is an important measure of goat farming performance. Daniel et al (2010) noted net farm income analysis enables the estimation of the total expenses (costs) as well as various receipts (revenue or returns) within the production period. Goat farming in Banjarnegara is a sideline to the main job as traders, employee, and horticultural farmers.

Revenue from goat farming obtained from the sale of goats, sale of feces and the annual increase in livestock value. Revenue of goat farmers ranged between $\mathrm{Rp} 300,000.00$ - Rp $43,000,000.00$ per year averaged $\mathrm{Rp}$ $4,269,382.02$ per year. Meanwhile, the average costs incurred for the production was $\mathrm{Rp}$
$1,904,427.53$ per year. An average income of goat farmers was $\mathrm{Rp} 2,364,954.49$ per year for 3 heads of goat.

Goat farming development in the Sub District of Karangkobar generates higher average revenue than other districts. Monthly average income of goat farmers in Banjarnegara was Rp 197,079.54, lower than Rp $920,000.00$ of regional minimum wage. Under these conditions, goat farming could not be used as a main source of income. Limited goat ownership is one factor of farmers' low income. Ogguniyi (2010) stated that the number of goats determined profitability and economic efficiency of goat farming. Assan (2014) explained that goat farming would play an important role by an increasing number of goats.

\section{Structure of Household Income}

Goat farming plays a prominent role in rural economy in supplementing the income of rural household, particularly the landless, marginal and small farmers. Household income of goat farmers in Banjarnegara sourced from the goats and non-goats based activities. The structure of household income of goat farmers was dominated by income from non-goat farming activities by 71 percent, while the contribution of goat farming was only by 29 percent. Nongoat farming activities involved rice and horticulture, farming, government employee and fish pond. These kinds of livelihood have contributed as much as 71 percent of household income. Most of the farmers do with rice farming, horticulture farming, fish pond, government employee as main livelihood. As a sideline, the goat farming has been able to contribute significantly to the family income. Agustian and Nurmanaf (2001) illustrates that farming was categorized as a sideline business if an income contribution to household income is less than 30 percent. Livestock activities were classified just an agricultural supporting commodity. 
The annual average household income of goat farmers in Banjarnegara was $\mathrm{Rp}$ 14,996,631.55 consisted of Rp 2,364,954.49 from goats farming and $R p 12,631,677.06$ from non-goats. Under these conditions, family of goat farmers remain relied on non-goat business. Revenue contribution of goat farming still has the potential to be improved so it can be used as an opportunity to increase the economic capacity of farmer's household. Devendra (2001) suggested that an increase in the number of goats was managed by the farmers will be able to increase production and profitability of farmers. Increased production and profitability can further enhance the contribution of goats farming to the household income. Thus the improvement of the production system and the number of business scale can be done immediately to improve revenue and economic efficiency.

\section{Distribution of Household Income}

Household income of goat farmers in Banjarnegara includes income from goat farming, merchants, farm labor, clerks, and other entrepreneurs. The household income was varied enough among farmers. The diverse of income because farmers do more than one activity or each member of the household has a different activity. Increased farmer income is the key in the development of farmers in rural communities aimed at reducing poverty. According to Remi and Tjiptoherijanto (2002), the main cause of household poverty is low income.

Income distribution is one aspect of poverty that needs to be seen as basically a measure of relative poverty. Income inequality among households of goat farmers was done using Gini Coefficient measurements. Result showed inequality of income distribution in total goat farming family in Banjarnegara.

Gini Coefficient of total household income of goat farmers was 0.562 . The value above the illustrated index occurs at high inequality income of farmer's household among members of society. The high level of total income

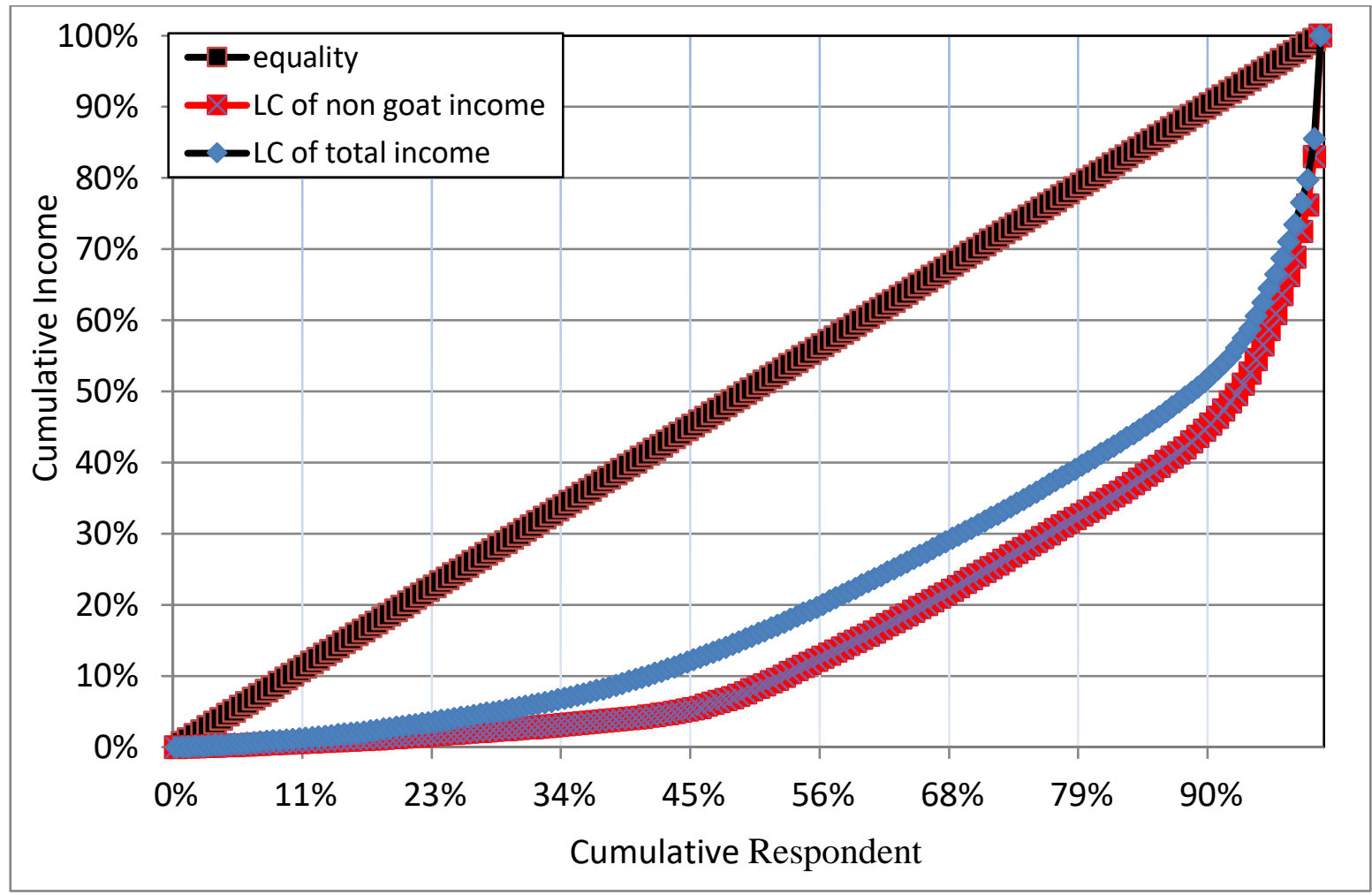

Figure 1. Lorenz Curve (LC) of Goat Farmer Households Income 
inequality is due to a greater relative inequality in non-goat farming income. The value of Gini Coefficient of non-goat income reached 0.658 which illustrates very high inequality on nongoat income. Partially, the income of farmers in the Susukan subdistrict describes a high disparity. Rahman (2015) mentioned nonagricultural income significantly increases consumption and inequality. The more unequal distribution of non-farm income is a key factor explaining the rise in inequality in household income. Their conclusion implies that, more farmers continuing move their attention to non-farm sectors, income inequality of farmer households in rural areas will continue to worsen. Income of non-goat farming, which contributed 71 percent of total household income has widen the gap between lower and upper income households. As confirmed by Zhu and Luo (2008), when participation in non-farm activities is highly selective, non-farm income tends to increase income disparities, particularly in poorer areas.

\begin{tabular}{cc} 
Tabel 1. Distribution of Household Income \\
\hline $\begin{array}{c}\text { Cumulative } \\
\begin{array}{c}\text { Percentage of } \\
\text { Households }\end{array}\end{array}$ & $\begin{array}{c}\text { Cumulative Percentage of Total } \\
\text { Households Income (\%) }\end{array}$ \\
\hline 10 & 1.10 \\
20 & 2.96 \\
30 & 5.62 \\
40 & 9.29 \\
50 & 15.25 \\
60 & 22.83 \\
70 & 30.83 \\
80 & 40.21 \\
90 & 51.41 \\
100 & 100.00 \\
\hline
\end{tabular}

Income distribution among the selected farmers in the rural areas of Banjarnegara is presented in Table 1 . The bottom 10 percent goat farmer households earned $1.10 \%$ of the total income of all the selected goat farmer households, while the top 10 percent earned $48.59 \%$ or 44 -fold. Obvious contrast is seen from the fact that the bottom 50 percent goat farmer households accounts for $15.25 \%$ of the total.

\section{Conclusions}

Goat farmer household in the rural area of Banjarnegara earns $R p$ 14,996,631.55 annually. Income from goat farming fractions a small portion of total household income. The goat farmer household earns $\mathrm{Rp}$ 2,364,954.49 annually from goat farming. The income from non-goat farm activities remain dominating the household income structure by 71 percent. The study reveals a high income inequality among goat farmer's household due to a greater relative inequality in non-goat households income. Urgent effort is to increase the contribution of goat farming to total household income of goat farmers.

\section{References}

Agustian A and AR Nurmanaf. 2001. Kontribusi Usahatani Ternak Ruminansia Kecil Terhadap Pendapatan Rumahtangga Dan Prospek Pengembangannya Dalam Memanfaatkan Peluang Pasar Pada Masa Mendatang (Kajian Di Kabupaten Deli Serdang-Sumatera Utara). Seminar Nasional Teknologi Peternakan dan Veteriner.

Agwu NM and CO Orji. 2013. Empirical Analysis of Income Inequalities And Welfare Among Farmers In South Eastern Nigeria. The Journal of Agricultural Sciences. 8 (1).

Assan N. 2014. Opportunities and needs in development of smallholder goat production systems in Africa. Scientific Journal of Animal Science 3(8): 203-212.

Atkinson AB. 1970. On The Measurement of Inequality. Journal of Economic Theory. 2: 244263.

Banjarnegara Statistic Bureau. 2015. Banjarnegara in Figures. Banjarnegara.

Bellù LG and $P$ Liberti. 2006. Inequality Analysis : The Gini Index. Module 04. Food and Agriculture Organization of the United Nations. FAO. Rome, Italy.

Birthal, Pratap S, Digvijay S Negi, Awadesh K Jha and Dhiraj Singh. 2014. Income Sources of Farm Households in India: Determinants, Distributional 
Consequences and Policy Implications. Agricultural Economics Research Review. 27(1):37-48.

Daniel JD, AA Sanda and EF Adebayo. 2010. Net income analysis and efficiency of resource use among cotton farmers in the Southern part of Adamawa State, Nigeria. Agric. Biol. J. N. Am. 1(6).

De Maio FG. 2007. Income inequality measures. Journal of Epidemiology and Community Health. 61(10).

Devendra C. 2001. Small Ruminants : Imperatives for Productivity Enhancement Improved Livelihood and Rural Growth. Asian Aust J.Anim.Sci. 14 (10).

Fang Z, Z Junpeng and D Rongjie. 2013. Estimating Gini Coefficient Based on Hurun Report and Poverty Line. Open Journal of Statistics. 3:167172.

Ogunniyi LT. 2010. Factors Influencing the Economic Efficiency of Goat Production In Ogbomoso Agricultural Zone, Oyo State, Nigeria. Animal Research International 7(1): 1129 - 1133.

Ogunniyi LT, AA Adepoju and F Olapade-Ogunwole. 2011. Comparative Analysis of Poverty and Income Inequality Among Food Crop and Livestock Farmers in Ilesa Metropolis, Osun State Global Journal of Human Social Science. 11 (5).
Puskur R. 2006. Investing in Livestock Development in Water-Scarce Semi-Arid Watersheds: Technological, Institutional and Policy Dimensions. paper prepared for presentation at the International Association of Agricultural Economists Conference, Gold Coast, Australia, August 12-18.

Rahman S. 2015. Micro-determinants of Income Inequality and Consumption in Rural Bangladesh. Journal of Poverty Alleviation and International Development. 6(2).

Remi S dan Tjiptoherijanto. 2002. Kemiskinan dan Ketidakmerataan di Indonesia. Rineka Cipta, Jakarta.

Todaro M. 1999. Pembangunan Ekonomi di Dunia Ketiga. Edisi Keenam. Penerbit Airlangga. Jakarta.

Todaro $M$ and SC Smith. 2006. Economic Development. Ninth Edition. Pearson Education Limited. United Kingdom.

Zhu, N and X Luo. 2008. The Impact of Remittances on Rural Poverty and Inequality in China. Policy Research Working Paper. 4367. The World Bank. East Asia and Pacific Region. Poverty Reduction and Economic Management Department. 